\title{
Do Flood Mitigation and Natural Habitat Protection Employment Reduce Youth Offending?
}

\author{
Michael A. Long ${ }^{1} \cdot$ Rebecca Oswald ${ }^{2}$. \\ Paul B. Stretesky ${ }^{2} \cdot$ Sarah Soppitt $^{2}$
}

Published online: 11 January 2018

C) The Author(s) 2018. This article is an open access publication

\begin{abstract}
The present study examines the association between employment and offending for a sample of young offenders who are paid to work in a pilot programme known as the Skill Mill. First, we analyse a sample of 39 youths over a period of 10 years (40 quarters) to determine whether Skill Mill employed youth are more likely to desist from offending than a control group of youth who are not employed in the Skill Mill. Those youths employed by the Skill Mill committed 1.12 fewer offences per quarter than the control group $(p<0.001)$. In addition, offending rates among the Skill Mill youths decreased by 0.99 offences per quarter after they began work $(p<0.001)$. Next, we review results from semi-structured interviews with current Skill Mill employees and their supervisor that helps to unpack why the Skill Mill has been successful in promoting desistance. We conclude that programmes like the Skill Mill can mark an important turning point, and more specifically, a hook for change in the lives of young offenders.
\end{abstract}

Keywords Youth $\cdot$ Desistance $\cdot$ Meaningful work $\cdot$ United Kingdom · Employment $\cdot$ Evaluation

Michael A. Long

michael.a.long78@gmail.com

Paul B. Stretesky

paul.stretesky@northumbria.ac.uk

Rebecca Oswald

rebecca.oswald@northumbria.ac.uk

Sarah Soppitt

sarah.soppitt@northumbria.ac.uk

1 Department of Sociology, Oklahoma State University, Murray Hall, Stillwater, OK 74078, USA

2 Department of Social Sciences, Northumbria University, Lipman Building, Newcastle upon Tyne NE1 8ST, UK 


\section{Introduction}

Common sense tells us that ex-offenders who are employed are more likely to desist from offending than those who are not employed. However, scholarship in this area suggests the relationship between employment and desistance is complex and has yet to be understood and examined for all ages, types of offenders and forms of employment (Paternoster et al. 2003; Sampson \& Laub 1993; Uggen \& Staff 2001; Wright \& Cullen, 2004). The object of the present study is to add to the desistance literature by examining the association between employment and offending frequency for a sample of young offenders who are put to work in a pilot programme known as the "Skill Mill." The Skill Mill employs young offenders to carry out flood mitigation and natural habitat protection projects for the community.

This research builds on previous work that examines the relationship between youth employment and desistance from criminal offending. Understanding the impact of pro-social work-based desistance programmes is crucial as these programmes are opening around the UK and are beginning to spread to continental Europe. The Skill Mill, Newcastle was established in late 2013 and in the time since, numerous branches have opened in the UK (Leeds, Cumbria and Liverpool) as well as in Tallinn, Estonia. This pilot study focuses on the Newcastle, UK branch of the Skill Mill to determine what positive effects going through a pro-social workbased desistance programme has on young ex-offenders.

Our evaluation is situated in a life course perspective. We draw upon the notion that the Skill Mill may provide life course transition or "turning points" for offending youth. We begin by examining the concept of turning points in promoting criminal desistance over the life course. Next, we briefly review the existing literature on the relationship between employment and criminal desistance among offending youth. We then describe the Skill Mill and suggest it should serve as a turning point that promotes desistance. After the methods and results sections, in the discussion we situate the findings in the existing literature.

\section{Youth employment and crime desistance}

Sampson \& Laub (1993, p. 8) stress the concept of 'turning points,' or those transitions that occur at specific points in time that may alter the life course toward or away from crime and deviance (see also Elder, 1994). In the case of criminal desistance, transitions may be effective in changing behaviour because they are rooted in "obligations" and "expectations" that bind individuals to social institutions (Sampson \& Laub 1993, p. 141). As Sampson and Laub (1993, pp. 8-9) observe, "Social institutions and triggering life events that may modify trajectories include school, work, the military, marriage, and parenthood" (italics added). This research adopts Sampson and Laub's view about turning points and proposes that pro-social youth employment can serve as a turning point for offenders and will therefore promote criminal desistance.

Unfortunately, it is difficult to determine whether employment can serve as an important turning point in the life course of young offenders (Uggen 2000; Lageson \& Uggen 2013). For instance, the literature on the relationship between employment and crime among young people is highly inconsistent. Indeed, a substantial body of empirical work now challenges the notion that youth employment is always desirable (Bachman \& Schulenberg 1993; Cullen et al. 1997; Safron et al. 2001; Wright et al. 1997). Thus, using employment to promote criminal desistance may be misguided. However, the criminology literature does document 
different effects for employment on crime depending upon the offender's age, intensity of employment, type of work and type of co-workers. We examine each of these issues and relate it to the potential for employment to enhance criminal desistance among youth.

\section{Age}

Staff \& Uggen (2003) observe that the impacts of employment on desistance vary by age, suggesting that work can reduce crime among adults but increases crime among young people. Staff \& Uggen (2003, p. 267) give three explanations why employment may increase crime and delinquency among youth. First, they draw upon Hirschi's (1969) social control theory to suggest that employment may take time away from families and schools and therefore weaken or disrupt attachments with the most basic institutions that inhibit delinquency at a young age. Second, they suggest that most youth are not mature enough to handle adult jobs and leisure activities that often accompany those jobs. Leisure activities associated with adult jobs place youth in positions where they may be dating early, using alcohol and drugs and missing school — all factors associated with delinquency. Third, Staff and Uggen suggest that employment may open up some opportunities for crime and delinquency in an atmosphere that is more likely to place stress (or strain, see Agnew 1992) on young people than adults.

\section{Work intensity}

Several empirical studies suggest that 'intense' work may lead to crime and deviance among youths. For instance, Bachman \& Schulenberg (1993) studied a sample of US high school seniors and found that as these young people worked more, their deviant behaviour and illicit drug use intensified (see also Safron et al. 2001). Furthermore, while Mihalic \& Elliott (1997) discovered that employed youth report more delinquency than unemployed youth, they also added that those who worked more than $20 \mathrm{~h}$ per week had much higher levels of self-reported deviance than those who worked less than $20 \mathrm{~h}$ per week. Bachman $\&$ Schulenberg (1993) also found that youths who work fewer hours per week are less likely to report trouble with the police and also less likely to engage in school-related misconduct than those who are intensively employed. Finally, Steinberg \& Dornbusch (1991) studied high school students in California and Wisconsin (USA) to determine if the amount of hours worked during the school year are related to drug use, skipping class and/or school performance. Two waves of the student self-report questionnaires suggest that as the number of hours worked increased, so did drug use, psychological symptoms and skipping class.

\section{Job type}

Despite the large body of research that documents a positive relationship between youth employment, work intensity, crime and deviance, there is reason to be optimistic that some types of employment may promote desistance under the right circumstances. That is, the type of job may influence the relationship between crime, delinquency and employment among youth (Agnew 1986; Uggen \& Staff 2001).

Uggen (1999) has suggested that job quality is related to criminal behaviour and points out that those ex-offenders who hold good jobs (defined according to job satisfaction within 
prestige-ranked occupations) are less likely to engage in crime than ex-offenders who hold poor jobs. One way that the type of employment may promote desistance from crime is through the concept of social capital. Wright et al. (1997) suggest that poor-quality jobs do not produce the kinds of social capital that will stimulate reductions in offending. That is, offenders employed in "fast food and service sector jobs in the secondary labour market [that] do not build social capital" are not likely to see reductions in offending over the life course (Wright \& Cullen 2004, p. 188).

Agnew (1986) has also pointed out that high-quality jobs are likely to reduce youth offending (see also Uggen \& Staff 2001). High-quality jobs that are stable can serve as a turning point in the lives of young people. Uggen \& Shannon (2014) also suggest that the type of job is an important consideration in determining whether crime and delinquency will increase or diminish. They suggest that "to effectively curb crime or drug use, a programme must meaningfully improve participants' employment prospects long-term” (Uggen \& Shannon 2014, p. 106).

Employment that promotes civic engagement may also encourage desistance from offending among chronic youth offenders. Uggen et al. (2006, p. 281) point out that in order to promote desistance, offenders need to have their "stigmatized status as outsiders [converted] to full democratic participation as stakeholders." This idea is also compatible with Maruna's (2001) assertion that types of work that help others and establish credibility are also likely to support desistance.

\section{Co-workers normativity}

The idea of deviance amplification suggests that ex-offenders are more likely to engage in future crime when they develop delinquent friendship networks through their workplaces. Therefore, employment may promote criminal desistance only where it brings offenders into contact with pro-social co-workers. Co-workers who support pro-social behaviours may provide an important source of social protection that helps increase the likelihood that a job will become a turning point that directs young ex-offenders away from crime. Paternoster et al. (2003, p. 327) suggest that the offender's employment surroundings matter, arguing that, "It may be that some types of jobs or employment experiences are criminogenic.. ..Other jobs, such as those where there is ample adult supervision and mentorship and where employees learn new skills, may actually inhibit antisocial behavior." Research confirms these observations. For instance, Wright \& Cullen (2004) examine data in the National Youth Survey (United States) to study whether pro-social coworkers help reduce drug use and delinquency. They suggest that work can disrupt those relationships and networks that encourage individuals to commit crime while fostering relationships that insulate the individual from crime. Thus, Wright \& Cullen (2004) point out that good jobs are "good" because they promote "informal social control" by "establishing social capital with employers" (p. 198). As a result, employment may reduce offending because some types of employment encourage the necessary type of social capital that can direct life trajectories away from crime. Thus, youth employment may also reduce offending when employees who hold pro-social values surround ex-offenders. Importantly, those youths with the highest levels of offending are more likely to be impacted by pro-social messages from their co-workers. For instance, Wright et al. (2001, p. 322) propose that "prosocial ties that deter crime, should deter it most strongly among individuals already prone to crime" (italics added). 


\section{Youth desistance employment?}

Inconsistencies in the youth employment/offending/desistance literature make it difficult to know how a youth offender programme that relies on employment might impact criminal desistance. Most studies on employment and delinquency among youth have been carried out in the United States. Additionally, although some research has found that youth employment increases the propensity for young people to drop out of school (e.g. Apel et al. 2008), to our knowledge, all existing studies that examine the employment-crime relationship study self-reported delinquency among large samples of youth who are still in school - the very group of youth whose offending levels may be adversely impacted by employment. To help fill this void in the literature we examine the Skill Mill programme for youth ex-offenders located in Newcastle upon Tyne, UK.

We suggest that the Skill Mill programme provides youth employment that builds social capital in a pro-social environment and fosters a sense of civic duty for those offenders that would not be in school or otherwise employed. Therefore, we argue that the Skill Mill may help establish an employment trajectory that can serve as an important turning point away from crime in the lives of young people.

\section{The Skill Mill}

The Skill Mill is a social enterprise that was created in Newcastle upon Tyne, UK, to help young ex-offenders desist from crime. In partnership with private and public organisations, including the Environment Agency, Northumbrian Water Ltd. and Newcastle City Council, the Skill Mill provides opportunities for education and job training in outdoor work, primarily in the areas of watercourse management and horticulture. Services offered by the Skill Mill include clearing waterways and digging channels, planting trees and gardening, household and industrial waste clearance, protecting species and flood defence work.

Young people are eligible for assignment to the Skill Mill if they are under the supervision of the Newcastle YOT, are not deemed a serious risk to themselves or others, and have completed their reparations to the community. Yet young people themselves must volunteer to be considered for the Skill Mill. This suggests that these ex-offenders are more motivated to change their life trajectories and put themselves on a path to desistance than those who do not. After an individual is selected for the Skill Mill, he or she completes six months of paid environmental work. The young people work approximately $30 \mathrm{~h}$ per week. Most young people also gain a qualification during their time at the Skill Mill, including a City \& Guilds Level 1 in Land Based Operations and the Construction Skills Certification Scheme Card. These are nationally recognised qualifications important for future jobs in environmental conservation and construction work. Skill Mill employment occurs in a pro-social environment because supervisors are trained (and want) to work with young offenders and they serve as important role models while simultaneously serving as educators and mentors in the programme.

Due to the clear benefits of the work done at the Skill Mill for the environment and the community, we suggest that the Skill Mill should encourage desistance for participating youth because it promotes socially meaningful employment. When the Skill Mill was initially set up, it was intended that each young person who successfully completed the Skill Mill would then be offered a "next step" job with one of the Skill Mill's private partner organisations. Unfortunately, over time, there appears to be fewer opportunities available for young people with these organisations. Despite this, the Skill Mill is dedicated to ensuring that these young 
people progress into full-time employment and therefore provide aftercare support. As a result, the programme offers all participants a realistic opportunity of eventually securing permanent employment. As long as this aim continues to be adhered to by the Skill Mill, it should be able to support permanent rather than temporal desistance from criminal activity.

Interestingly, Bushway and Apel (2012) argue that even if there is not a direct impact of employment on recidivism, participation in programmes like the Skill Mill signal a desire to desist from crime and should be seen as an important part of the re-entry process. Furthermore, some research has argued that the transition to employment is actually a result of desistance (Skardhamar and Savolainen 2014). This suggests that volunteering and completing the Skill Mill is a sign that young people want to change, or already have changed their behaviours. This strand of research appears to favour an integrated approach to desistance (Farrall and Bowling 1999) stressing the importance of both individual decisions (e.g. volunteering to participate in a work-based desistance programme) and social structural conditions (e.g. being employed). Therefore, the most appropriate way for understanding the desistance potential of the Skill Mill is that it hopes to create a "hook for change" (see Giordano et al. 2002), by accompanying other ongoing processes of desistance, such as motivation to change.

\section{Methods}

This is a mixed methods evaluation. First, we examine two groups of offenders using quantitative data: those who are placed in youth services and are assigned to the Skill Mill and those who are placed in youth services but not assigned to the Skill Mill. We then interview Skill Mill employees and their supervisor.

\section{Quantitative data}

To examine the effectiveness of the Skill Mill in reducing reoffending among young ex-offenders we employ random effects panel regression models based on longitudinal data for the period 20062015. Data was collected by the Newcastle Youth Offending Team (YOT) at three-month intervals; consequently, there are 10 years worth of data with four data points per year, or 40 data points for each individual in the dataset. There are two categories of offenders in the dataset: those who were referred to Newcastle YOT and will go or have gone into the Skill Mill, and those who were referred to Newcastle YOT and will not or have not gone into the Skill Mill. We refer to the second category of ex-offenders as the "control group," as one measure of the Skill Mill's success will be comparing those who attended the Skill Mill with similar ex-offenders who did not attend the Skill Mill. There were 14 individuals in the Skill Mill during the study time period and 25 individuals in the control group during that time. This results in 1560 observations for the analysis (i.e. 39 youth ex-offenders over 40 quarters). However, we then limited the sample to the criminologically relevant ages of 10 years old and above by eliminating all observations prior to each youth's tenth birthday, leaving 1215 usable cases for the statistical analyses.

We recognise that this is a small sample and acknowledge that it may have an impact on the findings. However, we trust our results for two reasons. First, we use multiple methods of estimation in both the bivariate and multivariate analyses, including nonparametric and resampling tests which are often more accurate in the analysis of small samples than traditional tests that are based on distributional assumptions. Second, we are evaluating the effectiveness of a programme; therefore, we are looking for evidence of an effect. Since it is more difficult to 
find an effect in studies with low power and small sample sizes, if an effect is found, there is reason to believe that it is evidence of a true effect in the population. Nonetheless, the small sample size may negatively impact its representativeness, so our results should be interpreted with caution as it is truly an evaluation of a pilot study.

In our analyses we control for several competing explanations of crime, including an individual's risk score, age, gender and ethnicity. We now turn to an explanation of the variables used in the analysis.

\section{Dependent variables}

Number of Offences: The number of criminal offences committed by an individual per threemonth period.

Offence Seriousness: The UK Home Office provides a numerical score to indicate the seriousness of an offence, where higher numbers correspond to more serious offences. Offence seriousness scores are assigned only when an offence occurs. Therefore, if an individual committed no offences during a three-month period, the Offence Seriousness variable for that three-month period is recorded as missing.

\section{The skill mill variable}

To test the effectiveness of the Skill Mill, we constructed a four-category variable that we then transformed into four dichotomous dummy variables. The four categories are made up of two binary categorical variables: (1) was the individual in the Skill Mill or was the individual a member of the control group, and (2) did the case in question occur before or after the individual entered the Skill Mill or during the equivalent time period for control group members. This resulted in four yes/no variables, with each individual data point representing an ex-offender who (1) eventually attended the Skill Mill (Skill Mill before), (2) is currently in or has already completed the Skill Mill (Skill Mill after), (3) has been in youth services an equivalent amount of time to those in the Skill Mill before category, but will not or did not attend the Skill Mill (Control before), or (4) has been in youth services an equivalent amount of time to those in the Skill Mill after category, but did not attend the Skill Mill (Control after).

\section{Control variables}

Risk: This variable is an additive scale of three measures of the risk/vulnerability of each youth ex-offender when they are first assessed by the Newcastle YOT. These measures include, (1) what is their risk of serious harm to themselves? $(0=$ low risk to $3=$ very high risk $),(2)$ what is their risk of serious harm to others? $(0=$ low risk to $3=$ very high risk $)$, and ( 3$)$ what is their Vulnerability Asset ${ }^{1}$ core profile? $(0=$ low vulnerability to 4 very high vulnerability). These three scores are summed for each individual in the study resulting in a risk/vulnerability

\footnotetext{
${ }^{1}$ The UK government and the Youth Justice Board for England and Wales use the Asset and AssetPlus Core profile forms to assess risk and protective factors that play a part in young people's offending. This intake procedure is mandated by the UK "Youth Justice National Standards" and provides information on the young person's risk of serious harm, intervention plan, final warning profile and bail supervision and support profile. This process occurs when the young person is first brought into the YOT (UK Government 2017). Numerous empirical assessments have found that it is a good predictor of re-offending (e.g. Wilson and Hinks, 2011; Baker et al. 2003).
} 
variable with a range of $0=$ lowest to 10 highest risk/vulnerability. The risk score is determined during the intake evaluation of a young offender by youth services.

Age: The age of the ex-offender during that three-month period.

Gender: The variable is coded as $1=$ female and $0=$ male. The variable is labelled "female".

Ethnicity: The variable is coded as $1=$ White British and $0=$ other. The variable is labelled "British white".

\section{Qualitative data}

To supplement the quantitative data we conducted semi-structured interviews with three current and one former Skill Mill employee and their work supervisor. The supervisor, Greg, ${ }^{2}$ has been the work supervisor for Skill Mill employees since it opened. The supervisor is the young people's main contact at the Skill Mill and goes out with them each day on the work site.

We gather the qualitative data for two main reasons. First, as noted above, the sample size in the quantitative analysis is small $\left(n_{\text {Skill Mill }}=14\right.$ and $\left.n_{\text {control }}=25\right)$ and the views of the participants and the supervisor will help contextualise the quantitative results and provide insight into how the programme helps (or does not help) the young people desist from crime. Second, the literature review highlights several variables that have been linked to desistance. While some of these have been included in the statistical models (e.g. age), others including, intensity of employment, type of work and type of co-workers are not included in the models because they are constants. All the young people who are in the Skill Mill are working the same job, for the same amount of hours, with the same coworkers, while those in the control group are not employed. Therefore, the effects of these variables cannot be analysed using the quantitative data. The qualitative interviews allow us to unpack the roles these variables play in the desistance process for Skill Mill participants.

\section{Analytical strategy}

To examine the effectiveness of the Skill Mill programme for reducing crime we used longitudinal data, where data was collected every three months over a 10 -year period (2006-2015) for a sample of 39 young people. We first examine the sample data for the two groups of youth ex-offenders. Specifically, we examine their age and offending profiles at the time of entry into the Skill Mill or the equivalent time-period for those in the control group. Through bivariate analyses we compare the two groups to determine if the exoffenders who enter the Skill Mill are similar on these characteristics compared with those who did not. This is a necessary first step in the evaluation. If the two groups are not similar, then the evaluation would lack validity and the Skill Mill programme could be seen as selecting participants based on their ability to complete the programme rather than on need.

We estimated random effects panel regression models to test the effects of the predictors on annual changes in the number of criminal offences and the seriousness of the offences during 2006-2015. There are two main options when modelling panel data: random effects

$\overline{2}$ The names of the supervisor and the four employees are pseudonyms to help retain confidentiality. 
and fixed effects (Rabe-Hesketh \& Skrondal 2008). We employed random effects, for two reasons. First, we wanted to include time-invariant predictors in the models (i.e. gender and ethnicity), and fixed effects models do not allow for these types of variables to be included. Second, we conducted a Hausman test to determine whether the variation across individuals was uncorrelated with the independent variables, an assumption of the random effects model. The results of the Hausman test, chi-square $(4)=9.86$, (not significant at $p<0.05$ ), fail to reject the null hypothesis that the errors are independent of the predictor variables, indicating that random effects models should be used (Rabe-Hesketh \& Skrondal 2008).

We modelled both dependent variables with a series of four equations. The first equation contains all of the control variables, while the second, third and fourth equations include three of the four treatment dummy variables in each model, with the comparison group changing in each model. This procedure allows us to make all of the comparisons that are necessary to address the research question, while controlling for risk, age, gender and ethnicity. We estimated the random effects models first with traditional standard errors and then with bootstrapped standard errors. Resampling procedures, like bootstrapping, have been shown to produce more accurate standard errors and hypothesis tests, than traditional approaches when analysing small samples. In the tables below we report only the results with the traditional standard errors; however, the findings using both methods provided extremely similar results. ${ }^{3}$

Following the quantitative analysis, we provide data from semi-structured interviews with Skill Mill employees and their supervisor. These data provide additional information about how the Skill Mill programme encourages desistance as well as providing insight into important desistance related variables that cannot be analysed quantitatively. We now turn to the analysis and results.

\section{Analysis and results}

\section{Descriptive and bivariate results}

Table 1 contains the descriptive statistics for the variables in the analysis. ${ }^{4}$ Table 2 reports the age and the offending and risk profiles of all ex-offenders in the study at the time of entry into the Skill Mill or equivalent time period for those in the control group. We tested the difference in means using two-independent samples $t$-tests and Mann-Whitney tests. We include the Mann-Whitney test results because it is a nonparametric test which may provide more accurate results due to the small sample size.

Based on the difference in means tests, the age of ex-offenders in the Skill Mill (16.6 years) is significantly greater than those in the control group (15.1 years). This is not surprising since those young people who are entering Skill Mill have to be working age to participate in the programme, while those in the control group do not. We did not find significant differences in the means of number of offences, offence seriousness and risk scores between the Skill Mill participants and those in the control group. This indicates that the offending and risk profiles between ex-offenders in both groups were similar.

\footnotetext{
${ }^{3}$ The results using bootstrapped standard errors are available upon request.

${ }^{4}$ See Appendix A for bivariate Pearson correlations for the variables in the analyses.
} 
Table 1 Descriptive statistics for variables in the analyses

\begin{tabular}{|c|c|c|c|c|c|}
\hline & Mean & Std. deviation & Min & Max & $n$ \\
\hline Number of offences & 0.818 & 2.000 & 0 & 18 & 1215 \\
\hline Seriousness of offence & 7.746 & 7.629 & 0 & 44 & 354 \\
\hline Risk & 2.928 & 2.504 & 0 & 9 & 1215 \\
\hline Age & 13.54 & 2.433 & 10 & 20 & 1215 \\
\hline Female & 0.105 & 0.306 & 0 & 1 & 1215 \\
\hline British white & 0.775 & 0.418 & 0 & 1 & 1215 \\
\hline
\end{tabular}

\section{Multivariate results}

Table 3 reports the results of random effects panel models for the prediction of number of offences. Based on models $1-4$, it is clear that risk $(p<0.05)$ and age $(p<0.001)$ are significantly related to number of offences, while female and British white are not. As risk and age increase, so does the number of offences committed.

Now we examine the effect that participation in the Skill Mill has on the number of criminal offences committed. We limit our discussion of models 2-4 to the relevant findings. In model 2 , the coefficient of Skill Mill after $(-1.12)$ is negative and significant $(p=0.000)$. The comparison group in this model is Control after. Therefore, ex-offenders who have entered and/or completed the Skill Mill average significantly fewer offences than members of the control group during the similar time period. Specifically, involvement in the Skill Mill reduces the number of offences by an average of 1.12 over each three-month period, compared to ex-offenders in the control group after treatment. In model 3, where Control before is the comparison group, the coefficient of Skill Mill before $(-0.09)$ is not significant $(p=0.690)$. This suggests that there is not a significant difference in number of offences between ex-offenders who eventually go on to the Skill Mill and those who do not. Finally, in model 4, where Skill Mill before is the comparison group, the coefficient of Skill Mill after $(-0.99)$ is significant $(p=0.000)$. This finding indicates that ex-offenders who have entered and/or completed the Skill Mill average significantly fewer offences than ex-offenders who have not begun the Skill Mill.

Table 4 reports random effects panel regression models for the prediction of seriousness of offence. The results in models 5-8 demonstrate that risk is a significant predictor of seriousness of offence $(p<0.01)$, while the effect of age on seriousness of offence is marginally significant $(p<0.10)$. In other words, increases in risk and age are associated with increases in seriousness of offence.

Models 6-8 examine the relationship between participation in the Skill Mill and offence seriousness. The coefficient of Skill Mill after $(-4.33)$ is negative and marginally significant $(p=0.068)$ in model 6. The control group for this comparison is Control after. Therefore, exoffenders who have entered and/or completed the Skill Mill average significantly lower offence scores compared to members of the control group during the similar time period. In model 7, the coefficient of Skill Mill before is not significant (the comparison group is Control before), indicating that there is not a significant difference in offence seriousness between exoffenders who eventually go on to the Skill Mill and those who do not. Finally, in model 8, where Skill Mill before is the comparison group, the coefficient of Skill Mill after is not significant. This suggests that ex-offenders who have entered and/or completed the Skill Mill 
Table 2 Demographic and offending data for youth in the sample upon entry of the Skill Mill or equivalent time in the control group

\begin{tabular}{|c|c|c|c|c|c|c|}
\hline & Skill Mill or control & Time at entry ${ }^{a}$ & Age & $\begin{array}{l}\text { Number } \\
\text { of offences }\end{array}$ & $\begin{array}{l}\text { Average offence } \\
\text { seriousness }\end{array}$ & Risk \\
\hline 1 & Skill Mill & 2013.4 & 18 & 63 & 2.5 & 5 \\
\hline 2 & Skill Mill & 2013.4 & 17 & 19 & 2.6 & 0 \\
\hline 3 & Skill Mill & 2013.4 & 17 & 2 & 3.0 & 4 \\
\hline 4 & Skill Mill & 2013.4 & 17 & 5 & 2.8 & 4 \\
\hline 5 & Skill Mill & 2014.2 & 16 & 25 & 2.9 & 4 \\
\hline 6 & Skill Mill & 2014.3 & 16 & 4 & 3.2 & 2 \\
\hline 7 & Skill Mill & 2014.2 & 15 & 5 & 3.1 & 1 \\
\hline 8 & Skill Mill & 2013.4 & 16 & 35 & 2.8 & 9 \\
\hline 9 & Skill Mill & 2014.2 & 16 & 4 & 2.0 & 7 \\
\hline 10 & Skill Mill & 2015.1 & 18 & 103 & 2.7 & 4 \\
\hline 11 & Skill Mill & 2015.1 & 17 & 8 & 3.1 & 0 \\
\hline 12 & Skill Mill & 2015.1 & 17 & 13 & 2.8 & 0 \\
\hline 13 & Skill Mill & 2015.1 & 17 & 15 & 2.9 & 0 \\
\hline \multirow[t]{2}{*}{14} & Skill Mill & 2015.1 & 16 & 6 & 3.1 & 1 \\
\hline & Average & & 16.6 & 21.9 & 2.8 & 2.9 \\
\hline 15 & Control & 2011.4 & 14 & 15 & 2.2 & 6 \\
\hline 16 & Control & 2012.1 & 14 & 10 & 2.8 & 6 \\
\hline 17 & Control & 2015.1 & 16 & 9 & 2.4 & 3 \\
\hline 18 & Control & 2014.4 & 17 & 19 & 3.5 & 3 \\
\hline 19 & Control & 2014.3 & 15 & 41 & 2.6 & 0 \\
\hline 20 & Control & 2014.2 & 17 & 46 & 3.3 & 4 \\
\hline 21 & Control & 2014.3 & 16 & 40 & 2.4 & 0 \\
\hline 22 & Control & 2012.4 & 13 & 3 & 3.0 & 0 \\
\hline 23 & Control & 2012.3 & 15 & 10 & 3.3 & 0 \\
\hline 24 & Control & 2011.4 & 15 & 3 & 2.0 & 0 \\
\hline 25 & Control & 2015.1 & 17 & 18 & 2.8 & 4 \\
\hline 26 & Control & 2014.4 & 14 & 48 & 2.9 & 4 \\
\hline 27 & Control & 2014.3 & 15 & 23 & 2.9 & 4 \\
\hline 28 & Control & 2014.3 & 15 & 10 & 3.5 & 0 \\
\hline 29 & Control & 2014.4 & 13 & 5 & 2.8 & 0 \\
\hline 30 & Control & 2014.2 & 17 & 18 & 3.0 & 3 \\
\hline 31 & Control & 2015.1 & 17 & 12 & 2.9 & 6 \\
\hline 32 & Control & 2015.1 & 15 & 6 & 2.5 & 0 \\
\hline 33 & Control & 2015.1 & 14 & 6 & 3.0 & 6 \\
\hline 34 & Control & 2013.1 & 14 & 5 & 2.8 & 6 \\
\hline 35 & Control & 2014.4 & 15 & 57 & 3.1 & 6 \\
\hline 36 & Control & 2014.4 & 15 & 18 & 2.5 & 3 \\
\hline 37 & Control & 2015.1 & 14 & 20 & 2.8 & 1 \\
\hline 38 & Control & 2015.2 & 15 & 14 & 2.4 & 2 \\
\hline \multirow[t]{4}{*}{39} & Control & 2014.4 & 15 & 4 & 2.8 & 3 \\
\hline & Average & & 15.1 & 18.4 & 2.8 & 2.8 \\
\hline & st ( 2 ind. Sample) & & $-4.2 * * *$ & -0.5 & -0.1 & -0.2 \\
\hline & ann-Whitney $(z)$ & & $-3.6^{* * * *}$ & -0.5 & -0.4 & -0.2 \\
\hline
\end{tabular}

Notes: $* * * p<0.001,{ }^{*} p<<0.01,{ }^{*} p<0.05$ significance (two-tailed). ${ }^{\mathrm{a}}$ The number after the decimal point signifies which quarter (3-month period) of the year the measurement took place

average roughly the same level of offence seriousness as ex-offenders who have not yet begun the Skill Mill. Although this finding is not significant, this may be due in part to the small sample size of the Skill Mill after category, who also had offence seriousness scores. 
Table 3 Random effects coefficients $(b)$ and standard errors $(S E)$ for determinants of number of offences, 2006$2015\left(\mathrm{n}_{\text {individuals }}=39, \mathrm{n}_{\text {observations }}=1215\right)$

\begin{tabular}{|c|c|c|c|c|c|c|c|c|}
\hline & \multicolumn{2}{|c|}{ Model 1} & \multicolumn{2}{|c|}{ Model 2} & \multicolumn{2}{|c|}{ Model 3} & \multicolumn{2}{|c|}{ Model 4} \\
\hline & $\begin{array}{l}b \\
(S E)\end{array}$ & $p$-value & $\begin{array}{l}b \\
(S E)\end{array}$ & $p$-value & $\begin{array}{l}b \\
(S E)\end{array}$ & $p$-value & $\begin{array}{l}b \\
(S E)\end{array}$ & $p$-value \\
\hline Risk & $\begin{array}{l}0.09 \\
(0.04)\end{array}$ & 0.035 & $\begin{array}{l}0.10 \\
(0.04)\end{array}$ & 0.023 & $\begin{array}{l}0.10 \\
(0.04)\end{array}$ & 0.023 & $\begin{array}{l}0.10 \\
(0.04)\end{array}$ & 0.021 \\
\hline Age & $\begin{array}{l}0.15 \\
(0.02)\end{array}$ & 0.000 & $\begin{array}{l}0.19 \\
(0.03)\end{array}$ & 0.000 & $\begin{array}{l}0.18 \\
(0.03)\end{array}$ & 0.000 & $\begin{array}{l}0.19 \\
(0.03)\end{array}$ & 0.000 \\
\hline Female & $\begin{array}{l}-0.47 \\
(0.35)\end{array}$ & 0.188 & $\begin{array}{l}-0.51 \\
(0.35)\end{array}$ & 0.149 & $\begin{array}{l}-0.51 \\
(0.35)\end{array}$ & 0.149 & $\begin{array}{l}-0.53 \\
(0.35)\end{array}$ & 0.131 \\
\hline British white & $\begin{array}{l}0.03 \\
(0.26)\end{array}$ & 0.919 & $\begin{array}{l}0.12 \\
(0.27)\end{array}$ & 0.659 & $\begin{array}{l}0.12 \\
(0.27)\end{array}$ & 0.650 & $\begin{array}{l}0.16 \\
(0.27)\end{array}$ & 0.549 \\
\hline Skill Mill before & & & $\begin{array}{l}-0.09 \\
(0.28)\end{array}$ & 0.739 & $\begin{array}{l}-0.09 \\
(0.23)\end{array}$ & 0.690 & & \\
\hline Skill Mill after & & & $\begin{array}{l}-1.12 \\
(0.34)\end{array}$ & 0.000 & $\begin{array}{r}-1.09 \\
(0.34)\end{array}$ & 0.000 & $\begin{array}{c}-0.99 \\
(0.28)\end{array}$ & 0.000 \\
\hline Control before & & & $\begin{array}{l}0.01 \\
(0.21)\end{array}$ & 0.943 & & & $\begin{array}{l}0.20 \\
(0.23)\end{array}$ & 0.384 \\
\hline Control after & & & & & $\begin{array}{l}0.08 \\
(0.21)\end{array}$ & 0.712 & $\begin{array}{l}0.26 \\
(0.28)\end{array}$ & 0.360 \\
\hline Constant & $\begin{array}{l}-1.46 \\
(0.40)\end{array}$ & 0.000 & $\begin{array}{l}-2.00 \\
(0.56)\end{array}$ & 0.000 & $\begin{array}{l}-1.88 \\
(0.44)\end{array}$ & 0.000 & $\begin{array}{l}-2.10 \\
(0.51)\end{array}$ & 0.000 \\
\hline Wald $\chi^{2}$ & 56.66 & 0.000 & 68.72 & 0.000 & 68.85 & 0.000 & 69.51 & 0.000 \\
\hline
\end{tabular}

Table 4 Random effects coefficients $(b)$ and standard errors (SE) for determinants of offence seriousness, 2006$2015\left(\mathrm{n}_{\text {individuals }}=39, \mathrm{n}_{\text {observations }}=354\right)$

\begin{tabular}{|c|c|c|c|c|c|c|c|c|}
\hline & \multicolumn{2}{|c|}{ Model 5} & \multicolumn{2}{|c|}{ Model 6} & \multicolumn{2}{|c|}{ Model 7} & \multicolumn{2}{|c|}{ Model 8} \\
\hline & $\begin{array}{l}b \\
(S E)\end{array}$ & $p$-value & $\begin{array}{l}b \\
(S E)\end{array}$ & $p$-value & $\begin{array}{l}b \\
(S E)\end{array}$ & $p$-value & $\begin{array}{l}b \\
(S E)\end{array}$ & $p$-value \\
\hline Risk & $\begin{array}{l}0.63 \\
(0.23)\end{array}$ & 0.006 & $\begin{array}{l}0.68 \\
(0.22)\end{array}$ & 0.002 & $\begin{array}{l}0.69 \\
(0.21)\end{array}$ & 0.001 & $\begin{array}{l}0.68 \\
(0.22)\end{array}$ & 0.002 \\
\hline Age & $\begin{array}{l}0.36 \\
(0.21)\end{array}$ & 0.086 & $\begin{array}{l}0.43 \\
(0.24)\end{array}$ & 0.068 & $\begin{array}{l}0.43 \\
(0.24)\end{array}$ & 0.067 & $\begin{array}{l}0.43 \\
(0.24)\end{array}$ & 0.067 \\
\hline Female & $\begin{array}{l}-1.91 \\
(1.94)\end{array}$ & 0.324 & $\begin{array}{l}-2.11 \\
(1.90)\end{array}$ & 0.268 & $\begin{array}{l}-2.14 \\
(1.82)\end{array}$ & 0.240 & $\begin{array}{l}-2.12 \\
(1.85)\end{array}$ & 0.252 \\
\hline British white & $\begin{array}{c}-0.79 \\
(1.38)\end{array}$ & 0.567 & $\begin{array}{l}-0.06 \\
(1.44)\end{array}$ & 0.966 & $\begin{array}{l}-0.02 \\
(1.37)\end{array}$ & 0.987 & $\begin{array}{l}-0.06 \\
(1.40)\end{array}$ & 0.968 \\
\hline Skill Mill before & & & $\begin{array}{l}-1.11 \\
(1.51)\end{array}$ & 0.464 & $\begin{array}{l}-0.90 \\
(1.22)\end{array}$ & 0.460 & & \\
\hline Skill Mill after & & & $\begin{array}{l}-4.33 \\
(2.37)\end{array}$ & 0.068 & $\begin{array}{l}-4.13 \\
(2.34)\end{array}$ & 0.078 & $\begin{array}{l}-3.23 \\
(2.20)\end{array}$ & 0.142 \\
\hline Control before & & & $\begin{array}{l}-0.17 \\
(1.19)\end{array}$ & 0.886 & & & $\begin{array}{l}0.92 \\
(1.23)\end{array}$ & 0.456 \\
\hline Control after & & & & & $\begin{array}{l}0.10 \\
(1.19)\end{array}$ & 0.934 & $\begin{array}{l}1.05 \\
(1.47)\end{array}$ & 0.474 \\
\hline Constant & $\begin{array}{l}1.36 \\
(3.28)\end{array}$ & 0.680 & $\begin{array}{l}0.14 \\
(4.03)\end{array}$ & 0.972 & $\begin{array}{l}-0.05 \\
(3.50)\end{array}$ & 0.988 & $\begin{array}{l}-0.96 \\
(3.80)\end{array}$ & 0.800 \\
\hline Wald $\chi^{2}$ & 16.87 & 0.002 & 21.38 & 0.003 & 22.92 & 0.002 & 22.23 & 0.002 \\
\hline
\end{tabular}




\section{Qualitative results}

\section{Desistance}

Both the supervisor and the Skill Mill employees noted that the Skill Mill has helped the young ex-offenders desist from crime. The supervisor Greg said that the Skill Mill helps the young people by, "Stop[ing] them from reoffending. Gives them structure in their life...They get a taste of work. Like the work ethic." This was supported by one of the young people Sam, who noted that during the six months he was in the Skill Mill he has, "stopped getting in trouble with the police and that."Another young person, Gary, also replied that he had stopped getting in trouble with the police during his time at the Skill Mill. When asked what specifically stopped him from getting in trouble with the police Sam said, "Coming here like everyday...Cos when you've got a job it's pointless going out and getting in trouble cos you'll just lose your job, won't you." It appears that having the responsibility of a job and the work ethic that is necessary to show up every day and do a good job has helped the young people desist from crime.

It was also clear that the supervisor plays a large role in aiding the desistance process. Greg is much more than their work supervisor. He is also a teacher, friend, social worker and often serves as a parent - or as he puts it, "being in the father zone." For example, he teaches the young people how to act in public.

"Being polite to the public in all. It's like I say, what we take for everyday granted. What we want our kids, children to be like, know what I mean? They're not necessarily like that. They are frightened to talk to people, they think that people's after something or like questioning them all the time...For them to learn their please and thank-you's and don't litter and don't spit and its simple little things."

In addition to teaching the young people how to act in public, Greg also helps them with family issues, looks for jobs for them after they leave the Skill Mill and helps them get to interviews. These are not part of his supervisor duties; however, they clearly have a big impact on the young people as Julie, a female Skill Mill employee says of Greg, "he's my best pal."

The notions of meaningful work and civic engagement appear to have an impact on the young people as well. All of them recall times when members of the public told them how great the areas they were working on looked and that they were doing a good job for the community. As Julie noted when asked about how work for the Skill Mill was going so far:

"It's fine, it's really good crack an all. And especially like when you're in the countryside and that, you get like passer bys and stuff in the community just complimenting everything. Like because you're sitting there hours on end pulling stupid tree guards off you think that you're not doing anything but when you look back on yourself you think Jesus it actually does look different. And like three or four dog walkers go look 'you's have done a really good job, it looks so much better down there'".

This type of meaningful work and the civic engagement it brings with it have helped the young people feel good about not only having a job and making money, but doing something for the community that brings praise from community members. 


\section{Variables not in the quantitative analysis}

As noted earlier, there are three variables that we could not include in the statistical analysis because they are constants; however, previous research has found they are linked to desistance. The first is intensity of employment, or how long the young people work per week. Much of the existing research (e.g. Bachman \& Schulenberg 1993; Safron et al. 2001) has found that working longer hours is associated with more deviant behaviour. However, the young people in the Skill Mill suggest that working more hours, for better wages, actually encourages desistance. As their supervisor Greg notes, the longer working hours helps by, "keeping them busy during the day. Taking up their time when usually they might have been on the streets and possibility offending. They also, after work, might not go out with friends in the evening because they have to be up for work the next day." All of the young people agree with Greg that being tired and keeping busy during the day helps keep them out of trouble.

Earning their own money allows the young people to pay their bills, rather than getting money from their social workers, is important to all of them. Julie says she "felt like a proper tramp" when she had to wait for money from her social worker, but now that she works for her own money she "gets like a good feeling." It appears to give them a sense of responsibility and pride.

The type of work that young people undertake has been linked to the likelihood of desistance (Uggen et al. 2006; Wright \& Cullen 2004). Research has argued that employment that promotes civic engagement can be beneficial for desistance (Uggen et al. 2006). As noted above, the positive responses and comments they have received from community members have had positive impacts on the young people. When asked if the work they are doing is important, Tim responds, "yes, it helps the wildlife" and Sam discusses the benefits to the environment of building fences to keep river banks from collapsing. Greg spends time educating them about nature which they seem to enjoy as most of them left school at an early age, as Julie says, "the majority of people haven't been to school so therefore you learn something new every day." All of the young people report enjoying working outside. For example, Sam worked in a garage for a short time but left soon after he started. He said he has stuck with the Skill Mill because he likes working outside more than being inside in the garage. While Skill Mill jobs are not high prestige, the young people we interviewed believe that what they are doing is important for the environment and community. They also emphasise that the work is desirable as it takes place outdoors. This combination of important outdoor work is what young people said helped them stay away from crime. Thus, our qualitative observations are consistent with Uggen et al.'s (2006) suggestion that civic engagement related activities may be an important aspect of desistance.

The type of co-workers has been shown to help with desistance, specifically being around pro-social co-workers. In the case of the Skill Mill, all employees are ex-offenders, so they do not really have the opportunity to be around pro-social co-workers. However, the three young people currently employed at the Skill Mill appear to be friends. The young people's biggest pro-social influence is Greg, the supervisor. As noted above, he teaches them how to act in public, educates them about nature, works hard on the job sites with them (even though he does not have to), talks to them about their family issues and generally looks out for them. In essence, he is a role model. All the young people have a lot of respect for him. 


\section{Discussion}

Research on employment and desistance is mixed and we argue that it is important to investigate those situations where offenders may benefit from employment because it promotes criminal desistance. Thus, we ask whether offenders who enter a social enterprise known as the Skill Mill are likely to desist from crime.

The quantitative analysis finds that at the time participants were referred to youth services, the ex-offenders who attended the Skill Mill had patterns of offending that were statistically similar to those of ex-offenders in the control group, indicating that comparisons between these two groups provide a valid evaluation of the effect of participation in the Skill Mill. Specifically, we found that participation in the Skill Mill significantly reduces the number of offences an individual commits compared to both (1) the same exoffenders before they began the Skill Mill and (2) ex-offenders in the control group who have spent a similar amount of time under the supervision of youth services. Furthermore, young ex-offenders who participate in the Skill Mill have significantly lower offence seriousness scores than similar ex-offenders in the control group. The qualitative data shows that the young ex-offenders currently in the Skill Mill benefit from working a relatively high number of hours, for decent wages, doing environmental work that provides them with some level of civic engagement. The young people note that working a lot helps keep them busy and out of trouble, which is contrary to much of the existing research on the employment-crime relationship (e.g. Bachman \& Schulenberg 1993; Safron et al. 2001); however, our results are in line with previous research that notes the importance of workrelated civic engagement to desistance (Uggen et al. 2006).

As we suggest, scholars have argued that the link between employment and crime desistance is dependent on the type of job the ex-offender holds (Agnew 1986; Bachman \& Schulenberg 1993; Uggen \& Staff 2001). Research has suggested that employment that includes mentorship and skills development (Paternoster et al. 2003), has high job satisfaction (Uggen 1999) and develops social capital (Wright et al. 1997) is particularly effective at promoting desistance from crime. These findings appear to hold true in the case of the Skill Mill. Young ex-offenders who participate in the Skill Mill have, for the most part, been successful in desisting from crime. We also suggest that an important part of the Skill Mill experience is that young ex-offenders are able to develop a sense of civic duty that helps them become connected to their communities. They are able to take pride in the work they do and the positive impact it has.

The success of the Skill Mill appears to stem from taking motivated youth ex-offenders, providing them with a job that pays relatively well, gives them a chance to do good for their communities and provides some civic reattachment. These things coupled with a supervisor who educates them about the work they are doing and how to act appropriately in public, looks out for them, helps out with family and other personal issues and is their friend, has resulted in these young people predominately desisting from crime. These results provide support for an integrated theory of desistance that takes into account both individual decisions and structural components (Farrall and Bowling 1999), and creates as Giordano et al. (2002) suggest, a hook for change for the young people in the Skill Mill.

Given the Skill Mill's success in reducing reoffending, primarily through flood mitigation and related work, youth services should consider involving young ex-offenders in similar types 
of meaningful employment that is beneficial to the community-in fact, the model is being replicated in other UK cities, such as Leeds, where a franchise of the Skill Mill opened in October 2015 and elsewhere in Europe, as a Skill Mill branch opened in Tallinn, Estonia in April 2016. These organisations will hopefully spur the creation of turning points by providing hooks for change in the lives of the youth ex-offenders who they employ.

\section{Appendix A}

Table 5 Pearson correlations for control variables

\begin{tabular}{llllll}
\hline & Number of offences & $\begin{array}{l}\text { Seriousness } \\
\text { of offence }\end{array}$ & Risk & Age & Female \\
\hline Number of offences & 1.000 & & & & \\
Seriousness of offence & $0.965^{* *}$ & 1.000 & & & \\
Risk & $0.132^{* *}$ & $0.252^{* *}$ & 1.000 & & \\
Age & $0.175^{* *}$ & $0.138^{*}$ & 0.047 & 1.000 & 1.000 \\
Female & $-0.079^{*}$ & $-0.136^{*}$ & $-0.100^{* *}$ & 0.001 & $0.184^{* *}$ \\
British white & -0.010 & -0.084 & $-0.110^{* *}$ & 0.026 & \\
\hline
\end{tabular}

Note: $* * p<0.001, * p<0.01$ (two-tailed)

Open Access This article is distributed under the terms of the Creative Commons Attribution 4.0 International License (http://creativecommons.org/licenses/by/4.0/), which permits unrestricted use, distribution, and reproduction in any medium, provided you give appropriate credit to the original author(s) and the source, provide a link to the Creative Commons license, and indicate if changes were made.

\section{References}

Agnew, R. (1992). Foundation for a general strain theory of crime and delinquency. Criminology, 30, 47-88. Agnew, R. (1986). Work and delinquency among juveniles attending school. Journal of Criminal Justice, 9, 19-41. Apel, R., Bushway, S., Paternoster, R., Brame, R., \& Sweeten, G. (2008). Using state child labor laws to identify the causal effect of youth employment on deviant behavior and academic achievement. Journal of Quantitative Criminology, 24, 337-362.

Bachman, J., \& Schulenberg, J. (1993). How part-time work intensity relates to drug use, problem behavior, time use, and satisfaction among high school seniors: Are these consequences or merely correlates? Developmental Psychology, 29, 220-235.

Baker, K., Jones, S., Roberts, C., \& Merrington, S. (2003). Validity and reliability of ASSET. London: Youth Services Board Assessed 25 September 2017. Available at https:/www.justice.gov.uk/about/yjb/.

Bushway, S. D., \& Apel, R. (2012). A signaling perspective on employment-based re-entry programming: Training completion as a desistance signal. Criminology \& Public Policy, 11, 21-50.

Cullen, F., Williams, N., \& Wright, J. P. (1997). Work conditions and juvenile delinquency: Is youth employment criminogenic? Criminal Justice Policy Review, 8, 119-144.

Elder, G. (1994). Time, human agency, and social change: Perspectives on the life course. Social Psychology Quarterly, 57, 4-15.

Farrall, S., \& Bowling, B. (1999). Structuration, human development and desistance from crime. British Journal of Criminology, 39, 253-268.

Giordano, P., Cernkovich, S., \& Rudolph, J. (2002). Gender, crime and desistance: Toward a theory of cognitive transformation. American Journal of Sociology, 107, 990-1064.

Hirschi, T. (1969). Causes of delinquency. Berkeley, CA: University of California Press. 
Lageson, S., \& Uggen, C. (2013). How work affects crime - and crime affects work-over the life course. In C. L. Gibson \& M. D. Krohn (Eds.), Handbook of life-course criminology: Emerging trends and directions for future research (pp. 201-212). New York, NY: Springer.

Maruna, S. (2001). Making good: How ex-convicts reform and rebuild their lives. Washington, DC: American Psychological Association.

Mihalic, S., \& Elliott, D. (1997). Short- and long-term consequences of adolescent work. Youth and Society, 28, $464-498$.

Paternoster, R., Bushway, S., Apel, R., \& Brame, R. (2003). The effect of teenage employment on delinquency and problem behaviors. Social Forces, 82, 297-335.

Rabe-Hesketh, S., \& Skrondal, A. (2008). Multilevel and longitudinal modeling using Stata (2nd ed.). College Station, TX: Stata.

Safron, D., Schulenberg, J., \& Bachman, J. (2001). Part-time work and hurried adolescence: The links among work intensity, social activities, health behaviors, and substance use. Journal of Health and Social Behavior, $42,425-449$.

Sampson, R., \& Laub, J. (1993). Crime in the making: Pathways and turning points through life. Cambridge, MA: Harvard University Press.

Skardhamar, T., \& Savolainen, J. (2014). Changes in criminal offending around the time of job entry: A study of employment and desistance. Criminology, 52, 263-291.

Staff, J., \& Uggen, C. (2003). The fruits of good work: Early work experiences and adolescent deviance. Journal of Research in Crime and Delinquency, 40, 263-290.

Steinberg, L., \& Dornbusch, S. M. (1991). Negative correlates of part-time employment during adolescence: Replication and elaboration. Developmental Psychology, 27, 304-313.

UK Government. (2017). Youth offenders: Assessment using 'Asset.' UK Government. Accessed on 25 September 2017. Available at https://www.gov.uk/government/publications/asset-documents.

Uggen, C. (1999). Ex-offenders and the conformist alternative: A job quality model of work and crime. Social Problems, 46, 127-151.

Uggen, C. (2000). Work as a turning point in the life course of criminals: A duration model of age, employment, and recidivism. American Sociological Review, 67, 529-546.

Uggen, C., Manza, J., \& Thompson, M. (2006). Citizenship, democracy, and the civic reintegration of criminal offenders. Annals of the American Academy of Political and Social Science, 605, 281-310.

Uggen, C., \& Shannon, S. (2014). Productive addicts and harm reduction: How work reduces crime-But not drug use. Social Problems, 61, 105-130.

Uggen, C., \& Staff, J. (2001). Work as a turning point for criminal offenders. Corrections Management Quarterly, 5, 1-16.

Wilson, E. \& Hinks, S. (2011). Assessing the predictive validity of the Asset youth risk assessment tool using the Juvenile Court Study (JCS). Ministry of Justice Research Series 10/11. Assessed 25 September 2017. Available at https://www.gov.uk/government/uploads/system/uploads/attachment_data/file/217365 /assessing-predictive-validity.pdf

Wright, B., Caspi, A., Moffitt, T., \& Silva, P. (2001). The effects of social ties on crime vary by criminal propensity: A life-course model of interdependence. Criminology, 39, 321-352.

Wright, J. P., \& Cullen, F. (2004). Employment, peers, and life course transitions. Justice Quarterly, 21, 183-205.

Wright, J. P., Cullen, F., \& Williams, N. (1997). Working while in school and delinquent involvement: Implications for social policy. Crime and Delinquency, 43, 203-221. 